\title{
The Story of Moses and Pharaoh in a Structural Anthropology Approach
}

\author{
Ahmad Umam Aufi \\ Universitas Islam Negeri Walisongo Semarang, Indonesia \\ aufiumam@gmail.com
}

\begin{tabular}{c}
\hline Article \\
Information \\
\hline
\end{tabular}

Received: August 13, 2020

Revised: October 31, 2020

Accepted: June 14, 2021

\section{Keywords}

The Story of Moses

and Pharaoh,

Anthropology-Structural,

Claude Lévi-Strauss

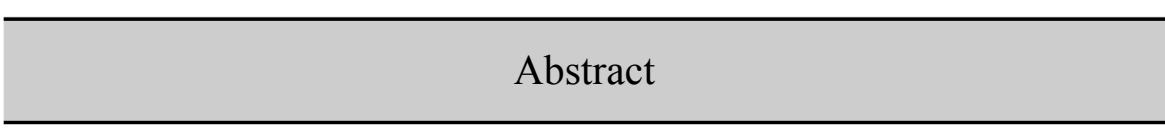

This study examined the story of Moses and Pharaoh as one of the Islamic narrative discourses in the Qur'an. Structural anthropology Claude Lévi-Strauss was used to analyze the story's structure or nature of the mind. The results of the study explicate that the story of Moses and Pharaoh had a structure of "struggle plot to convey the truth". Based on the episodes of the story showed a continuous transformation of structure and forms cylindrical triangle. Behind the story of Moses and Pharaoh was reflection of the developing culture in Islamic societies. First, there were some societies' components in the struggle process of the faithful in conveying the truth, both theologically or socio-politically. Such as the actor of social change (Moses), masses of people (the people of Moses), authorities who refused the change (Pharaoh and his leaders) and opportunist intellectuals (the magicians before being defeated by Moses), and organic intellectuals (the magicians after believing in the truth of Moses). Second, the community's culture was controlled by established authorities, the commitment of the truth will gain a refusal and despite resistance. The prerequisite to be able to undergo it was to confirm it rationally and empirically (according to the times).

Abstrak

Tulisan ini mengkaji kisah Musa dan Firaun sebagai salah satu khazanah naratif Islam di dalam al-Qur'an. Antropologi-struktural Claude Lévi-Strauss digunakan untuk melihat struktur atau alam pikiran di dalam sebuah kisah. Hasil studi menunjukkan bahwa kisah Musa dan Firaun terdapat struktur "alur perjuangan meyampaikan kebenaran." Struktur ini bertransformasi terus menerus pada episodeepisode di dalam kisah dan membentuk segitiga kiliner. Di balik kisah 
Musa dan Fir'aun terdapat cerminan kebudayaan yang berkembang dalam masyarakat Islam. Pertama, terdapat komponen-komponen dalam masyarakat pada proses perjuangan kaum beriman dalam menyampaikan kebenaran, baik secara teologis maupun sosial-politik. Seperti aktor perubahan sosial (Musa), massa atau rakyat (kaum Musa), otoritas yang menolak perubahan (Fir'aun dan para pemukanya) serta intelektual oportunis (para pesihir sebelum dikalahkan Musa) dan intelektual organik (para pesihir setelah meyakini kebenaran Musa). Kedua, dalam budaya masyarakat yang dikuasai oleh otoritas yang telah mapan (established), penyampaian kebenaran akan mendapatkan penolakan bahkan perlawanan. Prasyarat untuk mampu melaluinya ialah dengan membuktikan secara rasional dan empirik (sesuai zamannya).

\section{Introduction}

The stories in the Qur'an (qașah al-Qur'an) contain the stories of the previous people, previous prophets, and narratives of countries or regions in the past. In the al-Qur'an there are three types of describing stories. First, the stories of Prophet that contain dakwah, miracles, and the impact for those people who believe and disbelieve. Second, the stories of phenomenons and community in the past such as așhabul kahfi, Jalut and Talut, Dzulqarnain, așhab al-fil and other. Third, stories that are related to the events which are occurred at the time of the Prophet Muhammad for example the battle of Badr and Uhud in Ali Imran's letter and hijrah. The story of the Qur'an becomes a force that weakens ( $i$ 'jaz) those who deny Islam. ${ }^{1}$

In the story of al-Qur'an, the cultural values of the Muslim community are not explicitly conveyed. It is due to the al-Qur'an consisting of various fragments, characters, and events that hold the deepest meaning that must be revealed and analyzed by in-depth reading. Al-Qur'an' stories are not explaining coherently and in a chronological manner. The severability of one story to others contained in the al-Qur'an. This does not necessarily cause of loss in the essence

${ }^{1}$ Manna al-Qathan, Mabahis Fi 'Ulum Al-Qur'an (Kairo: Maktabah Wahbah, 2000), 300-301. of al-Qur'an. Fact, the Qur'an is filled with literary, philosophical, and miraculous elements such as the story of Moses and Pharaoh, the story of Abraham and Ishmael, the story of Mary, and others. $^{2}$

The purpose of a story in the Qur'an does not only dwell on the linguistic and historic aspects (asbab al-nuzul), but also on the cultural aspects that are displayed through certain structural models. Moreover, the structural transformation will also appear using a structural anthropological perspective. $^{3}$

In several studies of the Qur'an or more specific studies of stories in the Qur'an, most of them discuss the cause-effects of the revelation of the verse, the wisdom that can be used as lessons, the profile of a character, historicity, facts in a story, comparisons with other religious sources and others. However, a few studies of reviewing the Qur'an and stories in it by using anthropological techniques to explore the culture behind the stories in the Qur'an. The regularly repeated story in the Qur'an is the story of Moses and Pharaoh. It is not only in the Qur'an but can also be traced in various theological sources

\footnotetext{
${ }^{2}$ Ahmad Jadul Mawla dan Abu al-Fadhl Ibrahim, Kisah-Kisah Al-Qur'an (Jakarta: Zaman, 2009), 11.

${ }^{3}$ Hedddy Shri Ahimsa Putra, “The Living Al-Qur'an: Beberapa Perspektif Antropologi," Walisongo 20, no. 2 (2012): 255-56.
} 
such as the Bible and historical sources. Maurice Bucaille had examined this story by comparing theological sources, the Bible and the Qur'an, and historical sources. ${ }^{4}$ Likewise, Syukron Affani also did reconstructs the story of Prophet Moses by conducting comparative studies with the old testament.

The name Moses himself is called 137 times in the Qur'an. ${ }^{5}$ No prophet is mentioned in the Qur'an as much as that. The mention of the word Moses is found in 33 Surah. He further became one of the five prophets called ulul 'azmi. ${ }^{6}$ Indeed, Brannon M. Wheeler ${ }^{7}$ had investigated the story of Moses in the Qur'an by unraveling the roots of the tradition of interpretation of Muslim scholars and the sources of interpretation.

The story of the Prophet Moses is fascinating and meaningful because it is represented in full. One of them was when he dealt with Pharaoh. ${ }^{8}$ Moses and Pharaoh is a significant story in the recording of the Qur'an. This is apparent when dealing with the story of Moses, Pharaoh, and Bani Israel most experienced repetition in the Qur'an. ${ }^{9}$

However, there has been no examination of the story of Moses and Pharaoh that explores the hidden meaning of culture. Particularly by using a structural anthropological approach. An approach that reveals the structure of the cultures behind the story of Moses and Pharaoh.

Most studies of the Qur'an story is utilizing language and historical approaches. Hamada Hassanein ${ }^{10}$ had conducted a semiotic study of

\footnotetext{
${ }^{4}$ Maurice Bucaile, Moses and Pharaoh in The Bible, Qur'an and History (Kuala Lumpur: Islamic Book Trust, 2008).

${ }^{5}$ Brannon M. Wheeler, "'Moses,"” in The Blackwell Companion to the Qur'an, ed. by Andrew Rippin (USA: Blakcwell Publishing, 2006), 248.

${ }^{6}$ Anwar Mujahidin, Lokalitas Kisah Ibrahim Dan Musa; Antara Tafsir Al-Misbah Dan Tafsir Al-Azhar (Yogyakarta: Pustaka Pelajar, 2019), 141

${ }^{7}$ Brannon M. Wheeler, “Moses,"” in The Blackwell Companion to the Qur'an, ed. by Andrew Rippin (USA: Blakcwell Publishing, 2006).

${ }^{8}$ Anwar Mujahidin, Lokalitas Kisah Ibrahim Dan Musa; Antara Tafsir Al-Misbah Dan Tafsir Al-Azhar, 169.

${ }^{9}$ Ibid., 142.

${ }^{10}$ Hamada Hassanein, "A Semiotic Analysis of Moses and
}

the story of Moses and Pharaoh. The analytical technique was used to test the proposition descriptive, narrative and argumentative in the story. Anwar Mujahidin's study ${ }^{11}$ was conducted a comparative study between the story of Ibrahim and Moses in the local interpretation by Hamka and Quraish Shihab which also placed the historical element of the interpreter in the main position.

Nevertheless, the anthropological research of the story had also been carried out. M. Yasser Arafat ${ }^{12}$ was conducted a structural anthropological study focus on the story of Moses and Khidir in the al-Qur'an, Muhammad Ali Mustofa Kamal ${ }^{13}$ was studied elite community on the term al-mala' in the Qur' an adopting an anthropological approach, Imam Subchi ${ }^{14}$ was elaborated on Koentjaraningrat's anthropological approach in orchestrating stories of the Qur'an, and Anas Ahmadi ${ }^{15}$ had conducted a hermeneuticanthropological study of animal symbolism in the Qur'an. Nevertheless, there has been no anthropological study of the story of Moses and Pharaoh.

This study will analyze the inner structure or nature of the mind of the Muslim community until it is known the culture of the owner of the story which operates in the story of Moses and Pharaoh. This study will reveal the cultural structure behind the story of Moses and Pharaoh by describing

Pharaoh Narrative in the Qur'an," The American Journal of Semiotics 25, no. 1-2 (2009): 25-88.

${ }^{11}$ Anwar Mujahidin, Lokalitas Kisah Ibrahim dan Musa; antara Tafsir al-Misbah dan Tafsir al-Azhar. See also, Anwar Mujahidin, "Analisis Kisah Ibrahim, Musa Dan Maryam Dalam Tafsir Karya Mahmud Yunus, Hamka, Dan M. Quraish Shihab" (Ponorogo: STAIN Ponorogo, 2016).

${ }^{12}$ M.Yasser Arafat, "Analisis Antropologi-Struktural Kisah Musa Dan Khidir Dalam Al-Qur'an," Al-A'raf XV, no. 2 (2018).

${ }^{13}$ Muhammad Ali Mustofa Kamal, "Masyarakat Elite Dalam AlQur'an: Sebuah Pendekatan Antropologi Atas Term Al-Mala'," Jurnal Harmoni Multikultural Dan Multireligius 15, no. 1 (2016).

${ }^{14}$ Imam Subchi, "Antropologi Al-Qur'an: Integrasi Keilmuan Kisah-Kisah Al-Qur'an Dan Pokok-Pokok Antropologi Koentjaraningrat," Ilmu Ushuluddin 6, no. 1 (2019).

${ }^{15}$ Anas Ahmadi, "Symbolism of Sacred and Profane Animals in the Qur'an," Masyarakat, Kebudayaan Dan Politik 33, no. 1 (2020): 15-25. 
the structure and structural transformation to recognize how the operates culture behind the story. The Anthropological-structural approach is applied to examine the hidden cultural structures in the story of Moses and Pharaoh. The object to be discussed is the Surah al-A'raf verses 103137. ${ }^{16}$ The source of research data is based on Hamka's interpretation of Al-Azhar in the form of an interpretation of the story of Moses and Pharaoh in Surah al-A'raf verses 103-137. Tafsir Hamka had been selected for interpreting the story of Moses and Pharaoh in a surah al-A'raf paragraphs 103-137 due to he had divided the story into coherent episodes which are making it easier for authors to conduct structural analysis.

The reason for using anthropological-structural theory is because al-Qur'an is linguistic text and is a product of society's culture as well as creating a culture in civilization. ${ }^{17}$ Furthermore, culture can be approached by studying the language. The researcher will be known the culture of society using language. Language becomes an instrument for photographing logical relations, oppositions, and correlations between one another. ${ }^{18}$

\section{The Episodes and Ceriteme in the Story of Moses and Pharaoh}

The structure in the Lévi-Strauss concept was not related to empirical reality, yet the models that were formed. These models had several requirements to known as structural builders. First, it is a system. As a system, each element influences the other. There is no difference without the influence of other elements. Second, these models have been transforming into various models though of the same type. Third, the

\footnotetext{
${ }^{16}$ Hamka, Tafsir Al-Azhar, Vol. 4 (Singapura: Pustaka Nasional, n.d.).

${ }^{17}$ Nasr Hamid Abu Zayd, Mafhum Al-Nas: Dirasah Fi "Ulum alQur'an (Beirut: Almarkaz Althaqafi Al'arabi, 2014), 9.

${ }^{18}$ Susilo Pradoko, "Penerapan Paradigma Strukturalisme LeviStrauss Dalam Menganalisa Fenomena Seni Pertunjukan," Makalah Seminar Nasional Bahasa, Sastra, Dan Seni Dalam Perspektif Pluralisme Budaya, 2001.
}

devices that are used to predict how the latter react models on the effects of each element when these are modified. Thus, observed of the facts can be understood. ${ }^{19}$

In examining the structure, the story is divided into several episodes that are formed from ceriteme - ceriteme. The analysis of ceriteme which form of the episodes is carried out syntagmatically and paradigmatically. Hence, the structure in the story of Moses and Pharaoh can be known. Technically, the structural anthropological analysis includes several episodes of narration' stories, showing binary opposition and transformation, and revealing the deep structure. In examining the structure of the story of Moses and Pharaoh, The researcher examines of ceriteme-ceriteme which arrange the episodes syntagmatically. The division of episodes makes it easier for researchers to explore the structure in the story of Musa and Pharaoh. The story of Moses and Pharaoh which is analyzed in Surah al-A'raf verses 103-137.

\section{Apostolic mission episode}

In this episode, this story features the characters of Moses, Pharaoh, and the rulers of Pharaoh as the main characters. As recorded in verses 103-112:

"Then, after them, we sent Moses with our tokens unto Pharaoh and his chiefs, but they repelled them. Now, see the nature of the consequence for the corrupters! Moses said: "O Pharaoh! Lo! I am a messenger from the Lord of the World, approved upon condition that I speak concerning Allah nothing but the truth. I come unto you (Lord of Egypt) with a clear proof from your Lord. So let the children of Israel go with me." (Pharaoh) said: "if thou comes with token, then produce it, if thou art of those who speak the truth. Then he flung down his stuff and lo! It was a serpent manifest; and he drew forth his hand

\footnotetext{
${ }^{19}$ Claude Lévi-Strauss, Structural Anthropology (New York:
} Basic Books, 1963), 279-280. 
(from his bosom), and lo! It was white for the beholders. The chiefs of Pharaoh's people said: Lol this is some knowing wizard, who would expel you from your hand. Now what do ye advise?" they said (unto Pharaoh): "put him off (a while) - him and his brother - and send into the cities summoners, to bring each knowing wizard unto thee. ${ }^{20}$ "

The character of Moses (M) in this story appears as a messenger of God. Hamka by quoting the history of Abu Shaykh from Ibn Abbas explained that the name Musa comes from the old Coptic language, which consists of $\mathrm{Mu}$ and Sa. Mu means water and Sa means tree, with the result that Musa means water tree. It is because as a child he was thrown into the Nile in a wooden coffin and was kept in the Pharaoh's family environment. Therefore, he is called the child found in the water in a coffin..$^{21}$ According to Hamka, the word ba'atsna is heavier to arsalna. By the reason for Moses' struggle is more involved and convoluted. His mission was to fight Pharaoh to free the Children of Israel from Pharaoh's oppression and slavery. Prophet Moses came to bring verses of the greatness of God in face of Pharaoh. ${ }^{22}$ Prophet Moses came to bring verses of the greatness of God in face of Pharaoh.

Whereas, the character who faced Moses was Pharaoh (P). According to Quraish Shihab in Tafsir al-Misbah, Pharaoh is a term used to designate the name of the highest ruler in Egypt. According to Egyptian historians, the pharaoh referred to in this story is not Pharaoh or Ramses II, he known as Marenptah who adopted Moses as a child, yet the son of Ramses II who succeeded

\footnotetext{
${ }^{20}$ Meeftha, "ayatalQur'an.net," https://ayatalQur'an.net/2015/01/ surah-al-araf-\%D8\%A7\%D9\%84\%D8\%A3\%D8\%B9\%D8\% B1\%D8\%A7\%D9\%81-the-heights-terjemah-bahasa-inggris/, 2018, https://ayatalQur'an.net/2015/01/surah-al-araf-الأعرافthe-heights-terjemah-bahasa-inggris/.

${ }^{21}$ Hamka, Tafsir Al-Azhar, Vol. 4, 2465.

${ }^{22}$ Ibid., 2464.
}

his father in the XV century BC. ${ }^{23}$ In this story, Pharaoh is the king who oppressed the Children of Israel. Pharaoh is categorized in the group that does harm (mufsidun). In this episode, Pharaoh denies Moses to present the pieces of evidence of the truth that he brings.

Moreover, there are the leaders of Pharaoh (LP). As a great king, Pharaoh was supported by the rulers around him. Those who think that the verses of God's greatness which Moses brought are magic that will coup Pharaoh's power and expel them from the land of his dominion. ${ }^{24}$ They decided to encourage Pharaoh to take action against Moses' magic by gathering magicians. In this episode, the leader of Pharaoh (LP) who provokes Pharaoh and accuses Moses of being a magician and will seize Pharaoh's power. They advised Pharaoh to leave Moses and his brother first. In addition, they also suggested to Pharaoh to fight Moses by inviting magicians in the country.

These three characters are the main characters in this story. Although the background of the main character in this verse is not described in detail, they have a paired relationship. This relation appears as an opposite relation. Moses was a person who represented the oppressed people, as known as the Children of Israel, and became the messenger of God by bringing evidence of the truth. Whereas, Pharaoh and his leaders are kings and the ruling elite of the Copts (ancient Egypt) who doubt the evidence of the truth brought by Moses. furthermore, Moses came to free the oppression of the Children of Israel, while Pharaoh and his leaders were the people who oppressed the Children of Israel.

\footnotetext{
${ }^{23}$ M. Quraish Shihab, Tafsir Al-Misbah, Pesan, Kesan Dan Keserasian Al-Qur'an, Vol. 10 (Jakarta: Lentera Hati, 2007), 312. ${ }^{24}$ Hamka, Tafsir Al-Azhar, Vol. 4, 2469.
} 
This series of ceriteme present in the table below:

Table 1

\begin{tabular}{|c|c|c|c|}
\hline $\begin{array}{c}\text { Moses } \\
\text { (M) }\end{array}$ & $\begin{array}{c}\text { Representing } \\
\text { the } \\
\text { Oppressed } \\
\text { Nation (The } \\
\text { Children of } \\
\text { Israel) }\end{array}$ & $\begin{array}{c}\text { Presenting } \\
\text { evidence }\end{array}$ & $\begin{array}{c}\text { Saving the } \\
\text { oppression of } \\
\text { the Children } \\
\text { of Israel }\end{array}$ \\
\hline $\begin{array}{c}\text { Pharaoh } \\
\text { (P) }\end{array}$ & $\begin{array}{c}\text { The } \\
\text { oppressive } \\
\text { ruler (coptic) }\end{array}$ & $\begin{array}{c}\text { Refuse and } \\
\text { fight the } \\
\text { ovidence } \\
\text { of the truth }\end{array}$ & $\begin{array}{c}\text { Oppressing } \\
\text { the Children } \\
\text { of Israel }\end{array}$ \\
$\begin{array}{c}\text { Leaders } \\
\text { of }\end{array}$ & $\begin{array}{c}\text { The ruling } \\
\text { elite who } \\
\text { encourages } \\
\text { (LP) }\end{array}$ & $\begin{array}{c}\text { Declining } \\
\text { the } \\
\text { oppression }\end{array}$ & $\begin{array}{c}\text { Doing } \\
\text { oppression } \\
\text { against the } \\
\text { Israelites }\end{array}$ \\
\hline
\end{tabular}

Based on the table above it can be viewed that Moses (M) is in opposition to Pharaoh (P) and Pharaoh's Leader (LP). They are opposite on the position, status, and interests that they carry. M's defense is recognized when he goes to $\mathrm{P}$ to counter the harm he does. By bringing evidence of the truth, $M$ aims to reveal the truth about God, and P wonders it. M's opposition was also recognized when he wanted to liberate the Children of Israel. M occupies the position of liberator from oppression and $\mathrm{P}$ and LP occupies the position of oppressor.

$\mathrm{P}$ and LP are in opposition to $\mathrm{M}$ due to P's concerns are threatened. P's power by exploiting the Children of Israel threatened the arrival of $\mathrm{M}$ who would defeat the Children of Israel. $\mathrm{P}$ also senses that his power is threatened because $M$ brings evidence of the truth that absolute power belongs to God who controls nature.

\section{Episodes of Apostolic Evidence}

In this episode, to demonstrate his apostolate to liberate the Children of Israel, Moses is confronted by the magicians sent by Pharaoh. This is recorded in verses 113-126:

"And the wizard came to Pharaoh, saying: "surely there will be a reward for us if we are victors." They said:"Throw!" And when they threw they cast a spell upon the people's eyes, and overawed them, and produced a mighty spell. And we inspired Moses (saying): "throw thy staff!" and lo! it swallowed up their lying show. Thus was the truth vindicated and that which they were doing was made vain. Thus were they there defeated and brought low. And the wizards fell down prostrate, crying: "we believe in the Lord of the worlds, the Lord of Moses and Aaron." Pharaoh said: "ye believe in him before I give you leave! Lo! This is the plot that ye have plotted in the coty that ye may drive its people hence. But ye shall come to know! Surely I shall have your hands and feet cut off upon alternate sides. Then I shall crucify you every one." they said:" Lo! We are about to return unto our Lord!' thou takes vengenace on us only for as much as we believed the tokens of our Lord when they came unto us. Our Lord! Vouchsafe unto us steadfastness and make us die as men who have surrendered (unto three)"

The magicians (Ma) requested Pharaoh for rewards and positions when they defeated Moses. They threw first. According to Hamka, these magicians do not have a sense of belonging to their country, they perceive an opportunity for the king who is under pressure, and they are desperately needed. ${ }^{25}$ This competition is held on a major holiday towards midday. Hari Raya is a day when people are decorated, cities are beautified and everyone is ordered to gather. ${ }^{26}$

Their confidence in defeating Moses has vanished when the magic which they displayed could be defeated by the miracle of Moses in the form of a stick being thrown and turning into a large snake that ate the magic of the magicians. Following witnessing the defeat and the truth of the proof (miracle) of Moses, the

\footnotetext{
${ }^{25}$ Hamka, Tafsir Al-Azhar, Vol. 4, 2471-2472.

${ }^{26}$ Ibid., 2472.
} 
magicians prostrated themselves and declared their happiness to Allah. With the result that they were ready to die in a Muslim state (surrender to Him). This death, according to Hamka, they became martyrs and publicly declared the people's disobedience that Pharaoh was not the real God. ${ }^{27}$ Albeit they were accused by Pharaoh of conspiring with Moses, they were honest in their knowledge and acknowledged the miracles that were exposed to them.

The character Moses (M) in this episode is faced with magicians who will fight him. Moses requested the magicians to cast his magic first. He got a revelation from God to throw his stick. Moses's scepter beats the magician's wand, thus the truth can beat falsehood.

Pharaoh $(\mathrm{P})$ had promised wages and positions for magicians if they were able to conquer Moses. Instead, they declared their faith in the Lord of Moses. In terms of Quraish Shihab and Hamka, these magicians have committed acts of treason against Pharaoh. Therefore, Pharaoh sentenced them to cut their hands and feet on a cross and be crucified. ${ }^{28}$ Pharaoh thought they dared to fight against his power.

The series of ceriteme that form this episode can be viewed in the table below:

Table 2

\begin{tabular}{|c|c|c|}
\hline $\begin{array}{c}\text { Magician } \\
\text { (Ma) }\end{array}$ & Moses (M) & Pharaoh (P) \\
\hline $\begin{array}{c}\text { Decline the } \\
\text { evidence of } \\
\text { the truth of } \\
\text { Moses }\end{array}$ & $\begin{array}{c}\text { Bringing the } \\
\text { truth } \\
\text { (miracle } \\
\text { wand) }\end{array}$ & $\begin{array}{c}\text { Reject the proof of } \\
\text { the truth of Moses } \\
\text { (gathering the } \\
\text { magicians) }\end{array}$ \\
$\begin{array}{c}\text { requesting) } \\
\text { for Pharaoh's } \\
\text { (reward }\end{array}$ & & \\
\hline
\end{tabular}

${ }^{27}$ Ibid., 2476.

${ }^{28}$ M. Quraish Shihab, Tafsir Al-Misbah, Pesan, Kesan Dan Keserasian Al-Qur'an, Vol. 5 (Jakarta: Lentera Hati, 2007), 208. See also, Hamka, Tafsir Al-Azhar, Vol. 4, 2475.

\begin{tabular}{|c|c|c|}
\hline $\begin{array}{c}\text { Against the } \\
\text { proofs of } \\
\text { the truth of } \\
\text { Moses } \\
\text { (throws } \\
\text { magic wand } \\
\text { and rope) }\end{array}$ & $\begin{array}{c}\text { Indicate } \\
\text { proofs of the } \\
\text { truth } \\
\text { (throws } \\
\text { sticks) }\end{array}$ & $\begin{array}{c}\text { Against the evidence } \\
\text { of the truth of Moses } \\
\text { (rewards the magicians } \\
\text { to fight Moses) }\end{array}$ \\
\hline $\begin{array}{c}\text { Receiving } \\
\text { the proofs of } \\
\text { the truth of } \\
\text { Moses }\end{array}$ & $\begin{array}{c}\text { show proof of } \\
\text { truth } \\
\text { (destroys } \\
\text { magic of } \\
\text { (becomes a } \\
\text { believer after } \\
\text { his magic is } \\
\text { defeated) }\end{array}$ & $\begin{array}{c}\text { Against the proofs of } \\
\text { the truth of Moses } \\
\text { (consider the } \\
\text { magicians treason } \\
\text { and punish them for } \\
\text { believing in Moses) }\end{array}$ \\
\hline \multicolumn{2}{|c}{} & \multicolumn{2}{|c}{} \\
\hline
\end{tabular}

Based on the table above, in this episode there are three characters, namely the magicians (Ma), Moses (M) and Pharaoh (P). All the characters that appear have a paired and opposite relationship with one another.

Ma's character is in opposition to $\mathrm{M}$ when he receives $\mathrm{P}$ 's offer to defeat $\mathrm{M}$. Ma demands wages and position from $P$ to against $M$. In that position and situation, $\mathrm{Ma}$ is paired with $\mathrm{P}$ because he declined the evidence of the M's truth. Ma is also in opposition to $\mathrm{P}$ due to he was defeated by $\mathrm{M}$ and believes in the evidence of the M's truth. In this position and situation, Ma is paired with $\mathrm{M}$ as people who believe in Allah.

The character $\mathrm{M}$ is an opponent to $\mathrm{P}$, who rejects the evidence of the truth by bringing Ma to confront him. M is also in opposition to Ma when Ma accepts P's offer to fight $M$ with his magic. $\mathrm{M}$ failed Ma when he defeated Ma and believed in the evidence that $\mathrm{M}$ brought.

Figure $\mathrm{P}$ is in opponent to $\mathrm{M}$ because he rejects the evidence of truth brought by M. P demands LF to provide the advice to deal with $\mathrm{M}$. $\mathrm{P}$ was further gathered Ma to confront M. P did this because he was threatened with the arrival of $M$ who brought evidence of the truth and the mission to liberate the Children of Israel. P was likewise in opposition to Ma when Ma was defeated and believed in M's truth. P punished Ma by crossing 
their arms and legs and crucifying him. However, $P$ pairs up with Ma when both of them against the evidence for M's truth.

\section{Episodes of Denial and Warning}

This episode describes the disaster in the form of Pharaoh and the power elite and the arrival warning from God for the king of oppression, Pharaoh, which is a disaster. As mentioned in verses 127-132:

"The chiefs of Pharaoh's people said:"(o king), wilt thou suffer Moses and his people to make mischief in the land, and flout thee and thy gods?" He said:"we will slay their sons and spare their women, for Lo! We are in power over them." And Moses said unto his people:"seek help in Allah and endure. Lo! The earth is Allah's. He given it for an inheritance to whom he will. And lo! The sequel is for those who keep their duty (unto Him)." They said:" we suffered hurt before thou cames unto us, and since thou hast come unto us." He said:" it may be that your Lord is going to destroy your adversary and make you viceroys in the earth, that He may see how ye behave." And we straitened Pharaoh's folk with famine and dearth of fruits, that peradventure they might heed. But whenever good befell them, they said:" this is ours; and whenever evil smote them they ascribed it to the evil auspices of Moses and those with him. Surely their evil auspice was only with Allah. But most of them knew not. And they said:" whatever portent thou brings wherewith to bewitch us, we shall not put faith in thee."

In this episode, Moses tried to lead the Children of Israel even more after Pharaoh punished the magicians. This created worries of the leaders of Pharaoh (LP) regarding the awakening of the consciousness of the Children of Israel. Thus, the leaders of Pharaoh (LP) urged Pharaoh (P) to catch firm action regarding Moses (M) and his people. They accused Moses (M) and his people of turning to worship the God of Moses and expelling Pharaoh from Egypt. As known, the ancient Egyptians had a belief that Pharaoh himself was a descendant of the Sun God who was given to command the earth, and Egypt was the core of the earth. ${ }^{29}$ According to their provocation and insistence, subsequently, Pharaoh (P) fetches policy.

Pharaoh (P) will punish the people of Moses (M). He would kill their son and let his daughter live. Pharaoh (P) declared that he had full power over them. Hence, he will not remain silent on what Moses and his people have done.

Moses (M) summoned his people to respond to the policy of the Pharaoh $(\mathrm{P})$. He directed his people to beg for help from God, patient, and trust that the victory belongs to those who fear Allah. However, his people remained pessimistic, hence Moses (M) assured his people that one day Pharaoh (P) and his people would be defeated and they (Moses' people) would become caliphs on earth.

This episode also revealed the Moses' people (MP). They seem pessimistic regarding what they are facing. This is due to the oppression of Pharaoh $(\mathrm{P})$ continued both before and after the arrival of Moses (M). Thus it as if they are not certain that they can escape the oppression of Pharaoh (P).

Episode, the series of ceriteme appearances in the table below:

\footnotetext{
${ }^{29}$ Hamka, Tafsir Al-Azhar, Vol. 4, 2480.
} 
Table 3

\begin{tabular}{|c|c|c|c|}
\hline $\begin{array}{c}\text { Leaders } \\
\text { of Pharaoh } \\
\text { (LP) }\end{array}$ & $\begin{array}{l}\text { Pharaoh } \\
\text { (P) }\end{array}$ & $\begin{array}{c}\text { Moses } \\
\text { (M) }\end{array}$ & $\begin{array}{c}\text { Moses' } \\
\text { People } \\
\text { (MP) }\end{array}$ \\
\hline $\begin{array}{l}\text { Decline and } \\
\text { confront the } \\
\text { evidence of } \\
\text { the truth } \\
\text { (accusing } \\
\text { Moses of } \\
\text { being the } \\
\text { perpetrator } \\
\text { of riots or } \\
\text { destruction } \\
\text { in the land of } \\
\text { Pharaoh) }\end{array}$ & $\begin{array}{l}\text { (punishment } \\
\text { by killing a } \\
\text { baby boy) }\end{array}$ & $\begin{array}{l}\text { calm the) } \\
\text { Children } \\
\text { of Israel } \\
\text { over the } \\
\text { treatment of } \\
\text { Pharaoh by } \\
\text { requesting } \\
\text { for Allah's } \\
\text { assistant, be } \\
\text { patient, and } \\
\text { (optimistic }\end{array}$ & $\begin{array}{c}\text { Accepting } \\
\text { the } \\
\text { evidence } \\
\text { (Be patient } \\
\text { with } \\
\text { Pharaoh's } \\
\text { oppression } \\
\text { despite } \\
\text { pessimism) }\end{array}$ \\
\hline $\begin{array}{l}\text { (accusing } \\
\text { Moses of } \\
\text { being the } \\
\text { cause of } \\
\text { power and } \\
\text { the God of } \\
\text { Pharaoh } \\
\text { will be } \\
\text { abandoned.) }\end{array}$ & $\begin{array}{l}\text { Decline and } \\
\text { confront the } \\
\text { evidence of } \\
\text { the truth } \\
\text { (be } \\
\text { authoritarian } \\
\text { (qohirun) to } \\
\text { Moses and } \\
\text { his people) }\end{array}$ & $\begin{array}{l}\text { Show proof } \\
\text { of the truth } \\
\text { (ensuring } \\
\text { that } \\
\text { Pharaoh } \\
\text { would be } \\
\text { defeated } \\
\text { and the } \\
\text { Children of } \\
\text { Israel would } \\
\text { become } \\
\text { caliphs on } \\
\text { earth) }\end{array}$ & $\begin{array}{l}\text { Accepting } \\
\text { the } \\
\text { evidence } \\
\text { (trust in } \\
\text { God's } \\
\text { promise of } \\
\text { victory and } \\
\text { become } \\
\text { caliph on } \\
\text { earth) }\end{array}$ \\
\hline
\end{tabular}

In this episode, there are four characters involved. A fourth of them are the leaders of Pharaoh (LP), Pharaoh (P), Moses (M), and the Moses' people (MP). The four are polarized into two opposite poles. The P and LP are in opposition to the $\mathrm{M}$ and $\mathrm{KM}$ stronghold.

LP leaders from the outset have rejected the evidence of the truth that brought $\mathrm{M}$. In this episode, LP return affects by his provocative question posed to $\mathrm{P}$. LP suggested $\mathrm{P}$ demand firm action against $\mathrm{M}$ and MP. Thus in this case LF is in opposition to M and MP. Additionally, LP pairs up with $\mathrm{P}$ in terms of countering M's mission.

In the episode, Figure P, under the influence of LP, issues a policy due to M and MP's actions that harm him. $P$ assumes that the establishment of his belief and territory will be destroyed because of $\mathrm{M}$ and MP. Afterward, P punished MP in the form of killing MP's sons. In this case, $\mathrm{P}$ is in opposition to $\mathrm{M}$ and MP. In addition, $\mathrm{P}$ paired with LP in the context of their similarity in fighting M's mission.

Figure $\mathrm{M}$ is increasingly pressured by $\mathrm{P}$ 's policy. He is worried that MP's belief will waver due to P's punishment. Therefore, M advises MP by begging God for aid, being patient, and always optimistic. Moreover, M assures MP that $\mathrm{P}$ will be defeated and MP will become caliph on earth. In this case, he is paired with MP in the face of $P$ and LP and opposition to P and LP.

Nevertheless, MP senses that the representative of $\mathrm{M}$ has not provided any significant changes. MP is threatened continuously with P's oppression. Both before until after the arrival of $\mathrm{M}$. Thus, MP was convinced and promised victory by $M$. In this case MP was paired with $\mathrm{M}$ to facing $\mathrm{P}$ and LP and in opposition to P and LP who provided punishment in the form of killing MP's son.

\section{Punishment and Reward Episodes}

This episode is the final section of the story of Moses and Pharaoh which is a form of punishment for Pharaoh and his people and rewards for Moses and his people. As in verses 133-137 it is stated: "So we sent against them the flood and the locusts and the vermin and the frogs and the blood - a succession of clear signs. But they were arrogant and become a guilty folk. And when the terror fell on them they cried:" $O$ Moses! Pray for us unto thy Lord, because he hath a covenant with thee. If thou removes the terror from us we verily will trust thee and will let the children of Israel go with thee. But when did remove from them the terror for a term which they must reach, behold! They broke ther covenant. Therefore we took retribution from them; therefore we drowned them in the sea: because they denied our revelations and were heedless of them. And we caused the folk who were despised to inherit the eastern parts of the land and the western 
parts there of which we had blessed. And the fair word of thy Lord was fulfill for the children of Israel because of their endurance; and we annihilated (all) that Pharaoh an his folk had done and that they had contrived."

In this episode, Pharaoh and his people are gaining disaster. The disaster included a long dry season and a shortage of fruits. When they obtain prosperity they assume it happened because of their efforts. Although when it comes to distress and calamity they accused Moses and his people that caused it. They insisted on never believe in Moses.

Thereafter they were punished by various disasters such as hurricanes, the plague of locusts, fleas, frogs, and blood everywhere. Nor are these disasters not enough to generate them to realize that they are sinners. Instead of believing, they brag about themselves.

At last, the punishment (rijzu) involved befell them. Quraish Shihab ${ }^{30}$ called this a disgusting disease. Thus they begged Moses to relieve the disease. They promised to Moses if he was succeeded in eliminating the disease they would believe and let Moses go with the Children of Israel.

However, they broke their promise. They chased Moses and his people when they were about to leave Egypt. then they reached the Red Sea, they were drowned and what Pharaoh had built was destroyed. According to Quraish Shihab, ${ }^{31}$ this destruction was in the form of a landslide that buried the buildings of the Pharaoh's kingdom. Meanwhile, Moses and the Children of Israel passed through the Red Sea safely. They got the territory that was promised to him because of their patience.

${ }^{30}$ M. Quraish Shihab, Tafsir Al-Misbah, Pesan, Kesan Dan Keserasian Al-Qur'an, Vol. 5, 212.

${ }^{31}$ Ibid., 214.
In this episode, the stories that arranged can be viewed in the following table:

Table 4

\begin{tabular}{|c|c|c|c|}
\hline $\begin{array}{l}\text { Pharaoh } \\
\text { and his } \\
\text { people (P } \\
\text { and PP) }\end{array}$ & $\begin{array}{l}\text { Reject the } \\
\text { evidence of } \\
\text { Moses' truth } \\
\text { (gains various } \\
\text { disasters and } \\
\text { accuses Moses } \\
\text { of being the } \\
\text { cause) }\end{array}$ & $\begin{array}{l}\text { Requesting } \\
\text { for proofs } \\
\text { of the truth } \\
\text { of Moses } \\
\text { (requested } \\
\text { Moses } \\
\text { to pray } \\
\text { for the } \\
\text { disaster of } \\
\text { rijzu to be } \\
\text { removed } \\
\text { and they } \\
\text { will } \\
\text { believe) }\end{array}$ & $\begin{array}{l}\text { Refuse the } \\
\text { evidence of } \\
\text { Moses' truth } \\
\text { (lying } \\
\text { about their } \\
\text { commitment } \\
\text { after the } \\
\text { disaster was } \\
\text { removed, } \\
\text { destroyed the } \\
\text { land that had } \\
\text { been built, } \\
\text { and drowned } \\
\text { in the sea.) }\end{array}$ \\
\hline & $\begin{array}{l}\text { Bringing the } \\
\text { truth }\end{array}$ & $\begin{array}{l}\text { Bringing } \\
\text { the truth }\end{array}$ & $\begin{array}{l}\text { Bringing the } \\
\text { truth }\end{array}$ \\
\hline $\begin{array}{c}\text { Moses } \\
\text { and his } \\
\text { people } \\
\text { (M and } \\
\text { MP) }\end{array}$ & $\begin{array}{l}\text { (be patient and } \\
\text { wait for the } \\
\text { consciousness } \\
\text { of Pharaoh } \\
\text { and his } \\
\text { people) }\end{array}$ & $\begin{array}{l}\text { (pray for } \\
\text { Pharaoh } \\
\text { and his } \\
\text { people } \\
\text { from the } \\
\text { disaster of } \\
\text { rizju) }\end{array}$ & $\begin{array}{l}\text { (Moses and } \\
\text { his people } \\
\text { were saved } \\
\text { and got the } \\
\text { promised } \\
\text { territory) }\end{array}$ \\
\hline
\end{tabular}

In this episode, the characters are divided into two strongholds repeatedly. This time the $\mathrm{M}$ and MPstrongholds are in opposition to P and PP. P and PP yet insisted on rejecting the evidence that $\mathrm{M}$ brought. Then they are faced with a continuous disaster. However, it did not make P and PP aware instead blamed M even more. Finally, P and PP received a rijzu disaster and begged for M's prayer help. However, P and PP lied to them and because of it the country was sinking and burdened.

Meanwhile, M and MP were in opposition to $\mathrm{P}$ and $\mathrm{PP}$ yet they remained patient with $\mathrm{P}$ and PP's arrogance. Moreover, $\mathrm{M}$ would pray for $\mathrm{P}$ and PP to be saved from disaster rijzu although, in the end, they broke their promise. Finally, M and MP were rescued from the pursuit of $\mathrm{P}$ and $\mathrm{PP}$ and gain territory, as promised gratitude to their patience in dealing with $\mathrm{P}$ and $\mathrm{PP}$. 


\section{Deep Structure and Transformation in the Story of Moses and Pharaoh}

In analyzing cultural phenomena, the structure is divided into two, namely the surface structure and the deep structure. The surface structure is the outcome of the relations among elements contained in the syntagmatic level. The story of Moses and Pharaoh becomes the focus on the context of the syntagmatic level. Whereas, the deep structure is the result of obtaining and observing the opposition relations that are created from the surface structure which is continuously transformed in the form of binary opposition. ${ }^{32}$ This transformation is an embodiment of the structure in the form of repeatability. ${ }^{33}$ Anthropology structural analysis of the story, thus an attempt to unravel the logic or the mind of the story. By investigating the structure of a story, the empirical culture's face of the people who own the story can be observed.

A structure is a form of relationships among various units found in myths, literary works, or stories. The smallest units in Levi Strauss's terms are called myths (my themes), namely words, phrases, or sentences that show certain relationships. Meanwhile, Ahimsa mentions the term ceriteme-ceriteme, which are units of a series of sentences that contain certain meanings when connected to other ceriteme and form episodes that are interconnected with other episodes. ${ }^{34}$

In this story, it can be viewed the relationships that create the story of Moses and Pharaoh as described in the previous discussion. According to Lévi-Strauss in Structural Anthropology, these transfigured dialectical relations are called transformations. ${ }^{35}$ This face transformation is at the level of the container, not the content. Structuralism believes that transformation of face culture undergoes continuous at the level of the

\footnotetext{
${ }^{32}$ Claude Lévi-Strauss, 83.

${ }^{33}$ Heddy Shri Ahimsa Putra, Strukturalisme Lévi-Strauss Mitos Dan Karya Sastra (Yogyakarta: Kepel Press, 2006), 21 \& 69.

${ }^{34}$ Ibid., 263.

${ }^{35}$ Claude Lévi-Strauss, 86 .
}

surface structure, not the deep structure. ${ }^{36}$ Thus, the analysis transformation will notice changes in the deep structure at the level of the surface structure.

In this story, the transformation can be observed from the paired and opposite relationships which are created in each episode. The transformation appears from the first episode to the last. The inner structure transforms from the first episode to the last. In observing the transformation, the structure that operates in the story of Moses and Pharaoh is the structure of the plot of the struggle to convey the truth that forms a killiner triangle.

The struggle of Moses and his people in dealing with Pharaoh and his superiors presents a structure for the flow of struggle to convey the truth.

\section{The Structure of "The Struggle to Convey the Truth"}

Submit evidence of truth $=>$ Verification $=>$ decline and resistance $=>$ victory .

The plot of the struggle to convey the truth can be viewed from every episode in the story of Moses and Pharaoh. At the first of the story, Moses conveys the proof of truth by exposing a stick and a shining light in his hand and he receives rejection and resistance from Pharaoh and his leaders by gathering magicians. Altough Moses had been able to prove the truth.

In the second episode, this structure is transformed in the form of Pharaoh's rejection of the proof of Moses' truth after winning the battle against the magicians and making them submit and accept the truth that Moses brought. Nevertheless, Pharaoh refused and put up a fight by accusing the magicians of having compromised with Moses and punishing them.

The third episode revealing another transformation occurs when Moses proves the truth which he brought by successfully

${ }^{36}$ Heddy Shri Ahimsa Putra, Strukturalisme Lévi-Strauss Mitos Dan Karya Sastra, 21. 
eradicating the plague that befell Egypt. However, Pharaoh and his leaders refused and denied what Moses had said. The last episode revealed the transformation of evidence by the rescue of Moses and the Children of Israel from the pursuit of Pharaoh through the Red Sea and punished Pharaoh and his followers.

Based on the series of episodes, there are several conclusions drawn from the story of Moses and Pharaoh. First, the characters of this story are symbols that represent the meaning of the believers' struggle in conveying the truth, both theologically and socio-politically. While did the struggle process, there are components in society, in this case, the actor of social change (messenger) who is represented by Moses, the masses of people are represented by the Bani Israil (the Moses' people), the authority who refuses change is represented by Fir'aun and his leaders as well as opportunist intellectuals and organic intellectuals. Before recognizing the truth of Moses, the represented opportunist intellectuals are magicians and requesting crumbs of power whereas after they recognize the actual truth, the magicians become representing organic intellectuals. These components are related to each other and create a structure of "the struggle to convey the truth".

Second, the transmission of the truth will be rejected and yet resisted in a culture of a society that is controlled by an established authority. These challenges are the authoritarian regimes such as Pharaoh, the power of the political elite that supports him such as the leaders of Pharaoh, pragmatic intellectuals such as magicians who inquire about rewards and positions for their knowledge, and the masses of people who are already pessimistic due to long experienced injustice. Dialectics, rational and empirical evidence - based on the context of this story is the theological debates and the conquest of witchcraft - will be able to guide actors of social change to the entrance of 'victory'.

According to structural anthropology's point of view, these situations are a transformation (rather than appearance) of the deep structure. The story of Moses and Pharaoh is a 'language' and 'grammar' that operates behind that 'language' unconsciously and is continuously transforming in Muslim culture.

The transformation of the structure can be observed in the following table:

\section{Table 5}

\begin{tabular}{|c|c|c|}
\hline $\begin{array}{c}\text { Deep } \\
\text { Structure }\end{array}$ & Episodes & Surface Structure \\
\hline $\begin{array}{l}\text { 1. Submit } \\
\text { verification } \\
\text { of the truth } \\
\text { 2. Verification } \\
\text { 3. Refusal and } \\
\text { resistance } \\
\text { 4. Victory. }\end{array}$ & $\begin{array}{c}\text { First } \\
\text { Episode }\end{array}$ & $\begin{array}{l}\text { 1. Moses appeared as a } \\
\text { messenger of God and } \\
\text { saved the Children of } \\
\text { Israel } \\
\text { 2. Pharaoh commanded } \\
\text { Moses to prove the } \\
\text { truth and Moses threw } \\
\text { his staff } \\
\text { 3. Pharaoh's leaders } \\
\text { declined the evidence } \\
\text { of Moses' truth and } \\
\text { suggested Pharaoh } \\
\text { gather magicians to } \\
\text { combat Moses' magic } \\
\text { 4. Moses was able to } \\
\text { present evidence of his } \\
\text { truth through his staff } \\
\text { which turned into a } \\
\text { large snake and a bright } \\
\text { light spread of his hand }\end{array}$ \\
\hline & $\begin{array}{l}\text { Second } \\
\text { Episode }\end{array}$ & $\begin{array}{l}\text { 1. Moses was invited to } \\
\text { the palace } \\
\text { 2. Moses confers the } \\
\text { confirmation of his } \\
\text { truth with his staff } \\
\text { against the magicians } \\
\text { 3. Pharaoh accused the } \\
\text { magicians of conspiring } \\
\text { with Moses and } \\
\text { punished them } \\
\text { 4. Moses won the battle }\end{array}$ \\
\hline
\end{tabular}




\begin{tabular}{|c|c|}
\hline $\begin{array}{l}\text { Third } \\
\text { Episode }\end{array}$ & $\begin{array}{l}\text { 1. Moses continued to } \\
\text { lead and influence the } \\
\text { Children of Israel due } \\
\text { to his influence, } \\
\text { Pharaoh was anxious } \\
\text { and punished them by } \\
\text { killing his son } \\
\text { 2. Moses urges for prayer } \\
\text { and patience } \\
\text { 3. The Moses' people } \\
\text { were pessimistic } \\
\text { because they were } \\
\text { continuously } \\
\text { persecuted both at the } \\
\text { time of Moses' } \\
\text { appearance and before } \\
\text { 4. he land of Pharaoh's } \\
\text { power was punished by } \\
\text { drought and lack of } \\
\text { fruit }\end{array}$ \\
\hline $\begin{array}{l}\text { Fourth } \\
\text { Episode }\end{array}$ & $\begin{array}{l}\text { 1. The land of Pharaoh's } \\
\text { power was punished by } \\
\text { a hurricane, a plague of } \\
\text { locusts, fleas, frogs, } \\
\text { and blood } \\
\text { 2. Pharaoh begged Moses } \\
\text { to pray for the } \\
\text { disappear of disaster } \\
\text { and he and his } \\
\text { members promised to } \\
\text { accept Moses' truth } \\
\text { 3. Pharaoh and his } \\
\text { companions broke their } \\
\text { promise and chased } \\
\text { Moses while leaving } \\
\text { Egypt } \\
\text { 4. Moses and his people } \\
\text { were rescued while } \\
\text { Pharaoh and his people } \\
\text { drowned }\end{array}$ \\
\hline
\end{tabular}

Meanwhile, the Lévi-Strauss' cylindrical triangle model which is discussed in this story can describe the paired and opposite relationships as follows:

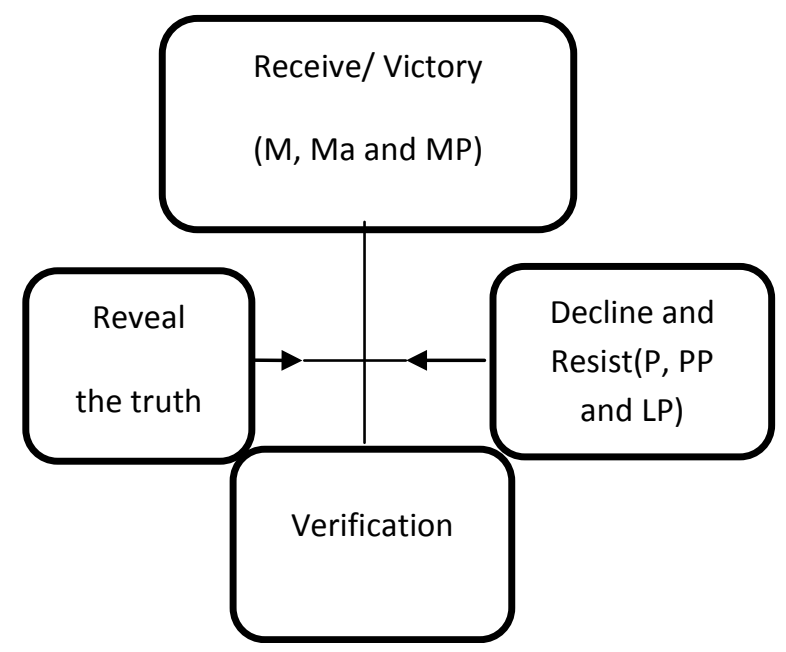

According to the model above, a cylindrical triangle is revealing the position and relationship inter-elements in a story which forms a structure. This cylindrical triangle represents each position of the character in the plot of struggle while conveying the truth.

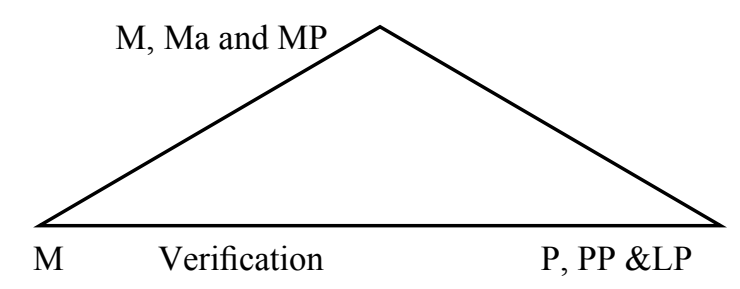

\section{Conclusion}

The story of Moses and Pharaoh in Surah alA'raf verses 103-137 does not simply describe the past situation. Behind the story, there is a structure of "the struggle to convey the truth" which includes:

\section{The structure of "the struggle to convey the truth"}


This structure is transformed continuously in every episode in the story of Moses and Pharaoh. Begin with episodes of apostolic missions, apostolic evidence, denial, and warnings, to the episodes of punishment and rewards.

There is a culture operating behind the story of Moses and Pharaoh. First, there are society's components in the process of the believers' struggle in conveying the truth, both theologically and socio-politically. Such as actors of social change (Moses), masses (Moses' people), authorities who resist change (Pharaoh and his leaders) as well as opportunist intellectuals (the mages before Moses defeated), and organic intellectuals (magicians who are believing the truth of Moses after the magic combat). Second, in a culture of a society that is controlled by an established authority, the commitment of the truth will be refused and indeed resisted. The prerequisite to be able to undergo it is to confirm it rationally and empirically (according to the times).

\section{References}

Ahmadi, Anas. "Symbolism of sacred and profane animals in the Qur'an." Masyarakat, Kebudayaan dan Politik 33, no. 1 (2020): 15-25.

al-Qathan, Manna. Mabahis fi 'Ulum al-Qur'an. Kairo: Maktabah Wahbah, 2000.

Arafat, M. Yasser. "Analisis Antropologistruktural Kisah Musa dan Khidir dalam Al-Qur'an." Al-A'raf XV, no.2 (2018).

Bucaile, Maurice. Moses and Pharaoh in The Bible, Qur'an and History. Kuala Lumpur: Islamic Book Trust, 2008.

Hamka. Tafsir Al-Azhar, Vol. 4. Singapura: Pustaka Nasional, n.d.

Hassanein, Hamada. "A Semiotic Analysis of Moses and Pharaoh Narrative in the Qur'an." The American Journal of Semiotics 25, no. 1-2 (2009): 25-88.

Kamal, Muhammad Ali Mustofa. "Masyarakat
Elite dalam Al-Qur'an: Sebuah Pendekatan Antropologi atas Term Al-Mala').” Jurnal Harmoni Multikultural dan Multireligius 15, no. 1 (2016).

Lévi-Strauss, Claude. Structural Anthrophology. New York: Basic Books, 1963.

Mawla, Ahmad jadul dan Abu al-Fadhl Ibrahim.

Kisah-Kisah Al-Qur'an. Jakarta: Zaman, 2009.

Meeftha. "ayatalQur'an.net." https:// ayatalQur'an.net/2015/01/surah-al-araf\%D8\%A7\%D9\%84\%D8\%A3\%D8\% B9\%D8\%B1\%D8\%A7\%D9\%81-theheights-terjemah-bahasa-inggris/, 2018. https://ayatalQur'an.net/2015/01/surah-alaraf-الأعر اف-the-heights-terjemah-bahasainggris/.

Mujahidin, Anwar. "Analisis Kisah Ibrahim, Musa dan Maryam dalam Tafsir Karya Mahmud Yunus, Hamka, dan M. Quraish Shihab." Ponorogo, 2016.

------. Lokalitas Kisah Ibrahim dan Musa; antara Tafsir al-Misbah dan Tafsir al-Azhar. Yogyakarta: Pustaka Pelajar, 2019.

Pradoko, Susilo. "Penerapan Paradigma Strukturalisme Levi-Strauss dalam Menganalisa Fenomena Seni Pertunnjukan." In Makalah Seminar Nasional Bahasa, Sastra, dan Seni dalam Perspektif Pluralisme Budaya, 2001.

Putra, Hedddy Shri Ahimsa. "The Living AlQur'an: Beberapa Perspektif Antropologi." Walisongo 20, no. 2 (2012): 255-56.

-------. Strukturalisme Lévi-Strauss Mitos dan Karya Sastra. Yogyakarta: Kepel Press, 2006.

Shihab, M. Quraish. Tafsir al-Misbah, Pesan, Kesan dan Keserasian Al-Qur'an. Vol. 10. Jakarta: Lentera Hati, 2007.

- Tafsir al-Misbah, Pesan, Kesan dan Keserasian Al-Qur'an. Vol. 5. Jakarta: Lentera Hati, 2007.

Subchi, Imam. “Antropologi Al-Qur'an: Integrasi Keilmuan Kisah-Kisah A1- 
Qur'an dan Pokok-Pokok Antropologi Koentjaraningrat." Ilmu Ushuluddin 6, no. 1 (2019).

Wheeler, Brannon M. "Moses." In The Blackwell Companion to the Qur'an.
Edited by Andrew Rippin. USA: Blakcwell Publishing, 2006.

Zayd, Nasr Hamid Abu. Mafhum Al-nas: Dirasah fi "Ulum al-Qur'an. Beirut: Almarkaz Althaqafi Al'arabi, 2014. 